\title{
GLOBAL DEVELOPMENT AND HUMAN RIGHTS
}

The Sustainable Development Goals and Beyond

From 2000 to 2015 the Millennium Development Goals (MDGs) mobilized external aid to finance life-changing services in the global South. However, in doing so, the organization failed to meet the challenges often associated with human rights initiatives, which are to make underprivileged communities independently prosperous, equitable, and sustainable.

In Global Development and Human Rights, Paul Nelson assesses the current thirty-year effort to make transformative changes in the global South by exploring how this disconnect from human rights weakened the MDGs reputation as a successful aid organization. To overcome the failings of the MDGs, the Sustainable Development Goals (SDGs) were formed in 2016 with the intention of managing the issues fundamentally ignored by the MDGs.

Drawing on twenty-five years of research on development goals, human rights, and the organizations that promote them, Nelson reasons that transformative change arises out of national and local movements, and shows how human rights can offer leverage and political support that help drive transformative national initiatives.

PAUL NELSON is an associate professor of international development at the University of Pittsburgh. 
(ii)

\section{UTP insights}

UTP Insights is an innovative collection of brief books offering accessible introductions to the ideas that shape our world. Each volume in the series focuses on a contemporary issue, offering a fresh perspective anchored in scholarship. Spanning a broad range of disciplines in the social sciences and humanities, the books in the UTP Insights series contribute to public discourse and debate and provide a valuable resource for instructors and students.

For a list of the books published in this series, see page 245. 


\section{GLOBAL DEVELOPMENT AND HUMAN RIGHTS}

\section{The Sustainable Development Goals and Beyond}

Paul Nelson 
(C) University of Toronto Press 2021

Toronto Buffalo London

utorontopress.com

Printed in the U.S.A.

ISBN 978-1-4875-0116-7 (cloth) ISBN 978-1-4875-1262-0 (EPUB)

ISBN 978-1-4875-2125-7 (paper) ISBN 978-1-4875-1261-3 (PDF)

\section{Library and Archives Canada Cataloguing in Publication}

Title: Global development and human rights : the sustainable development goals and beyond / Paul Nelson.

Names: Nelson, Paul J., 1956- author.

Series: UTP insights.

Description: Series statement: UTP insights | Includes bibliographical references and index.

Identifiers: Canadiana (print) 20210155248 | Canadiana (ebook) 20210155310 | ISBN 9781487501167 (cloth) | ISBN 9781487521257 (paper) | ISBN 9781487512620 (EPUB) | ISBN 9781487512613 (PDF)

Subjects: LCSH: Sustainable Development Goals. | LCSH: Sustainable development. | LCSH: Human rights.

Classification: LCC HC79.E5 N47 2021 | DDC 338.9/27 - dc23

University of Toronto Press acknowledges the financial assistance to its publishing program of the Canada Council for the Arts and the Ontario Arts Council, an agency of the Government of Ontario. 